\title{
EMPLOYING WEBSITE IN JAPANESE LEARNING AS AN INSTRUCTIONAL MEDIA FOR PEDAGOGICAL PURPOSE
}

\author{
Herniwati*, Noviyanti Aneros, Melia Dewi Judiasri \\ Fakultas Pendidikan Bahasa dan Sastra, Universitas Pendidikan Indonesia, Indonesia \\ *herniwati@upi.edu
}

DOI: $10.20884 / 1 . j 11 i .2019 .10 .2 .2080$

\begin{abstract}
Article History:
First Received:

ABSTRACT

$12 / 11 / 2019$

Industrial revolution 4.0 in the development of instructional media for

Final Revision:

Japanese language learning is one of the demands of the era that cannot be

$06 / 12 / 2019$ avoided anymore. Devices that cannot be released from the students' hands make it seems like it's the only source to search for information or answer in the learning process. Learning Japanese is not only through textbooks, but

Available online: students are able to develop the teaching materials in the form of narratives of tourism and cultural destinations in the city of Bandung using Japanese.

$30 / 12 / 2019$ Those narratives about the information of destinations are packaged into a website that can be accessed anytime and anywhere, as an interactive instructional media that can increase motivation and interest about the city of Bandung in Japanese. The development of this website is not only for Japanese learners, but also useful as a source of information for Japanese people who will visit the city of Bandung. The latest information about the city of Bandung using Japanese consists of historical sites, tourist attractions, museums, and culinary. Japanese learners can access them at any time and can be used as a medium for discussion, and learners can explain it again about the city of Bandung to their friends. This innovation of learning media is a solution in the era of industrial revolution 4.0 to improve Japanese language skills both orally and in writing.
\end{abstract}

Keywords: Instructional media, website, tourism

\section{INTRODUCTION}

To face the era of industrial revolution 4.0, education is required to form a creative, innovative and competitive generation. One of them can be achieved by optimizing the use of technology as educational equipment that is expected to produce output that can keep up with the era for the better. Indonesia also needs to improve the quality of graduate students befitting to the world of work and the demands of digital technology. Education 4.0 is a general term used by educational theorists to describe various ways of integrating cyber technology, both physically and not, into the world of learning. In order to actualize the technology of information and communication for learning in this era of industrial revolution 4.0, teachers must be able to explore the potential of students to develop creativity both in learning activities and in any field 
of science, including in learning Japanese. Japanese instructional media through the technology of information and communication is able to stimulate students' motivation in communicating either orally or in writing.

The use of technology has become an important part of the learning processin and out of the class (Ahmadi, 2018). World Wide Web (www) is also called the web, site, or website is an application and internet service that includes multimedia resources (Dimitrov \& Rumrill, 2003). Physically, web is a collection of personal computers, web browsers, connections to ISPs, computer servers, routers, and switches that are used to stream information and become the first medium for various parties involved (Herniwati et. al, 2019). The use of the internet network as a source and tools for learning can be implemented, as follows: 1. Resourcing is making the internet as a source for teaching. The role of the internet as a storehouse of information is used to obtain information and data relating to the teaching material. Information relating to the address of the site to be visited as a source of teaching material is known in advance through the information provided in the teaching handbook and other information. 2. Searching is the process of finding learning resources in order to complete the material to be delivered to students.According to Medina using multimedia and web learning resources may enrich the learning environment, enhance the learning process, make education more widely available, and produce cost effective solutions for the dissemination of knowledge (Medina, 2002). Thus, the development of Japanese instructional media through the website is one of the interesting parts, where students can develop brilliant ideas in their writing in Japanese, programmed and welldirected, for example: developing teaching materials of tourism information for Japanese tourists who will visit Bandung city in Japanese.

Herniwati et.al said Bandung as a tourism destination in West Java attracts both the domestic and foreign tourists. The Bandung's tourism is always visited by people throughout Indonesia and abroad, including Japan. Bandung is always crowded in the weekends and the major holiday by people whowant to enjoy the refreshing weather, the foods, and the places of interest that attract the visitors (Kementerian Pariwisata, 2018). The number of foreign tourists continues to grow every year. Biro Pusat Statistik (BPS) recorded the number of foreign tourist arrivals in July 2016 reached the highest record in one month, 1.03 million visits or increased $20.42 \%$ compared to the previous month. Sasmito (2016) said that the surge in the number of foreign tourist arrivals was $17.68 \%$ compared to the same period last year due to an intensive campaign from the government and also tourist destinations which became the tourist attractions in Indonesia (Oetomo \& Sutedjo, 2007). According to data from the Ministry of Tourism in 
2016, 473,616 Japanese visited Indonesia, and 1,474 visited Bandung (Rusman, 2017). The above description has proven that the tourism destinations of Bandung or "Paris Van Java" and "Kota Kembang" are the places that local and foreign tourists always want to visit. One reason is Bandung in 2008 was selected as a pilot project of a creative city in the Asia Pacific region by the British Council, in which Bandung became one of the benchmark cities of the creative industry in Indonesia (Sasmito, 2016). However, behind the beauty of Bandung's tourism destinations, there is lack of information about each tourism destination in a foreign language, especially in Japanese. If we try to find information on the internet, the websites are still challenging to find and to be accessed. This condition is due to the absence of Japanese people or practitioners who make the latest tourism destination information services in Bandung. In this era of technology and gadgets, all information should be obtained quickly in the cyberspace.

To overcome the problems above, Herniwati, Aneros \& Judiasri has developed the website "Bandung no Kankouchi" in the URL: https://www.bandung-no-kankouchi.comwhich contains various information in Japanese about Bandung city, which includes general information, tourism, history, culinary, shopping mall, restaurants, hotels and so on (Soedarsono \& Wiyancoko, 2014). The website is expected not only as information for Japanese tourists but also for students learning Japanese, the information on this website is expected to be used as an instructional media in developing Japanese speaking competencies. Students still do not have the courage in telling or explaining information directly related to Bandung city, this is because the information is still in Indonesian. In addition, the limitations of Japanese language competence of students in writing Japanese make it difficult for students to provide real information around them.

Thus, to overcome the problems above, there needs to be a new innovation in the development of Japanese language learning through instructional media on the website regarding information on Bandung tourism destinations, which are not only about tourism, but also the culture of the city of Bandung will be introduced in Japanese. With the aim of students being more skilled in speaking Japanese and also can introducing Bandung city to Japanese people. Furthermore, students are able to develop their writing competencies by adding up-to-date information about Bandung city in Japanese. In addition, the results of this study will be an alternative teaching material for Japanese language learners in Indonesia. So that the outcome of this study will be useful for Japanese tourists in particular and improve students' speaking and writing skills in learning Japanese.

Based on the background which is a common problem in this study, it can be further elaborated into several formulations of the problem, as follows, 1) Can the instructional media of 
Bandung tourism destination websites improve competency in writing Japanese? 2) Can the instructional media of Bandung tourism destination websites improve competency in speaking Japanese? 3) What is the students' response to learning Japanese using the website media information system for tourism and cultural destinations in Bandung city which was developed?

\section{METHOD}

\section{Research Method}

This study was conducted by pre-experiment method, one group pretest-posttest design, and questionnaires. Pretest and posttest design is widely used for measuring the change from experimental treatments in order to assess its impact.

\section{Subjects}

The target population for this experiment was students in Japanese Language Education in Universitas Pendidikan Indonesia who take Advance Japanese Speaking Class as an elective subject. The sample was one group that consisted of 15 students 6 semesters.

\section{Materials}

The material used in this research is the themes contained in the URL: https://www.bandung-no-kankouchi.com. Themes that are presented on the website, namely: 1) General information about the city of Bandung; 2) History, Museums, Places of Tourism, Culinary, Hotels, and Restaurants.

\section{Figure 1. website Bandung no Kankouchi}

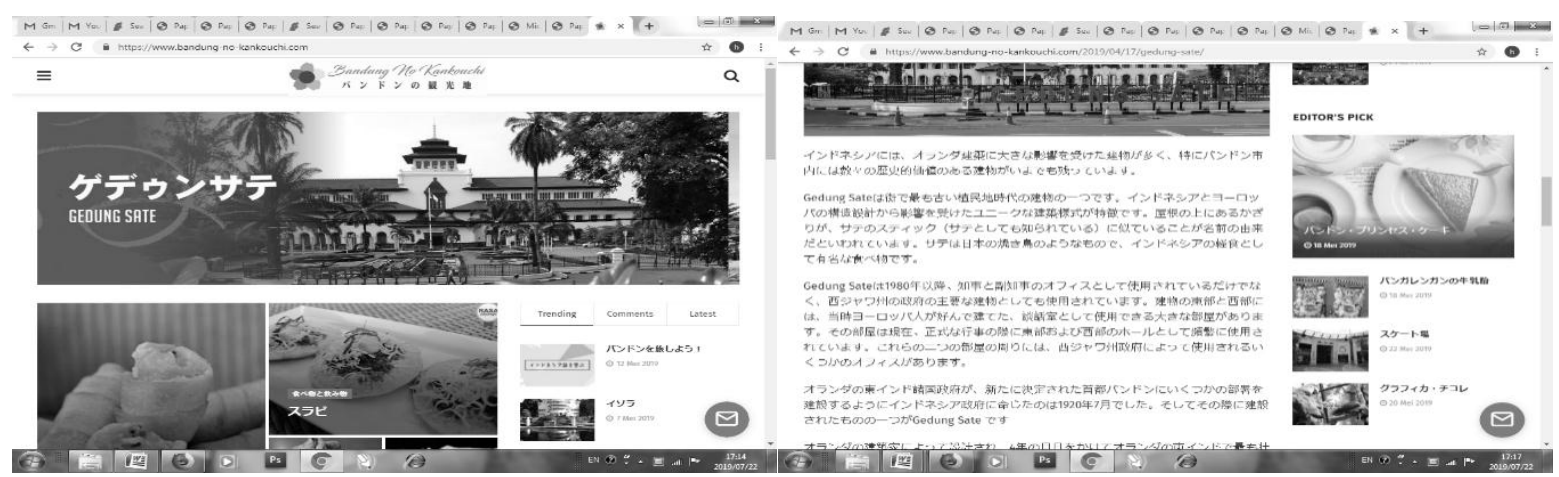


Figure 2. Website Bandung no Kankouchi Themes

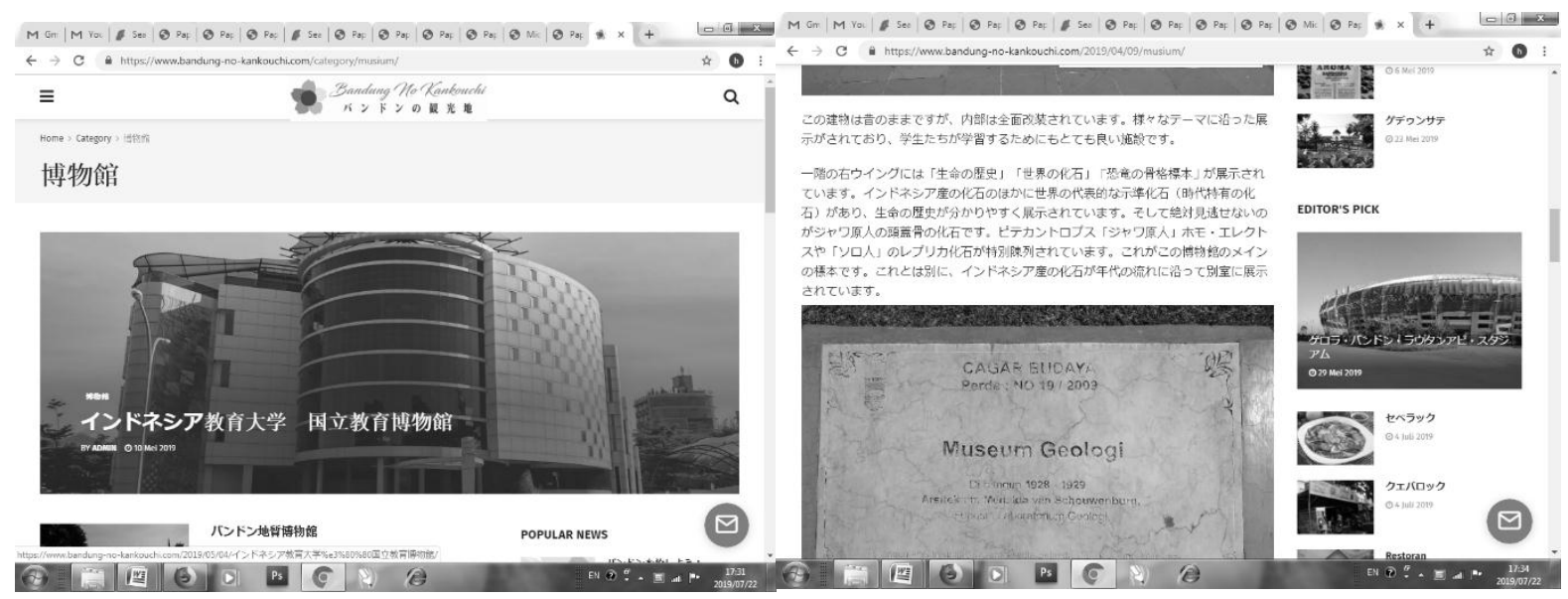

\section{Research Procedures}

This research was conducted four times in Sogo Nihongo course. This course applies four language skills, namely speaking, writing, reading and listening. The steps used in each meeting in this research, namely: 1) students choose a theme found on the website; 2) read the theme; 3 ) make narratives related to the chosen theme; 4) present the theme.

\section{FINDINGS \& DISCUSSIONS}

\section{Writing}

\section{Figure 3. Writing Skills}

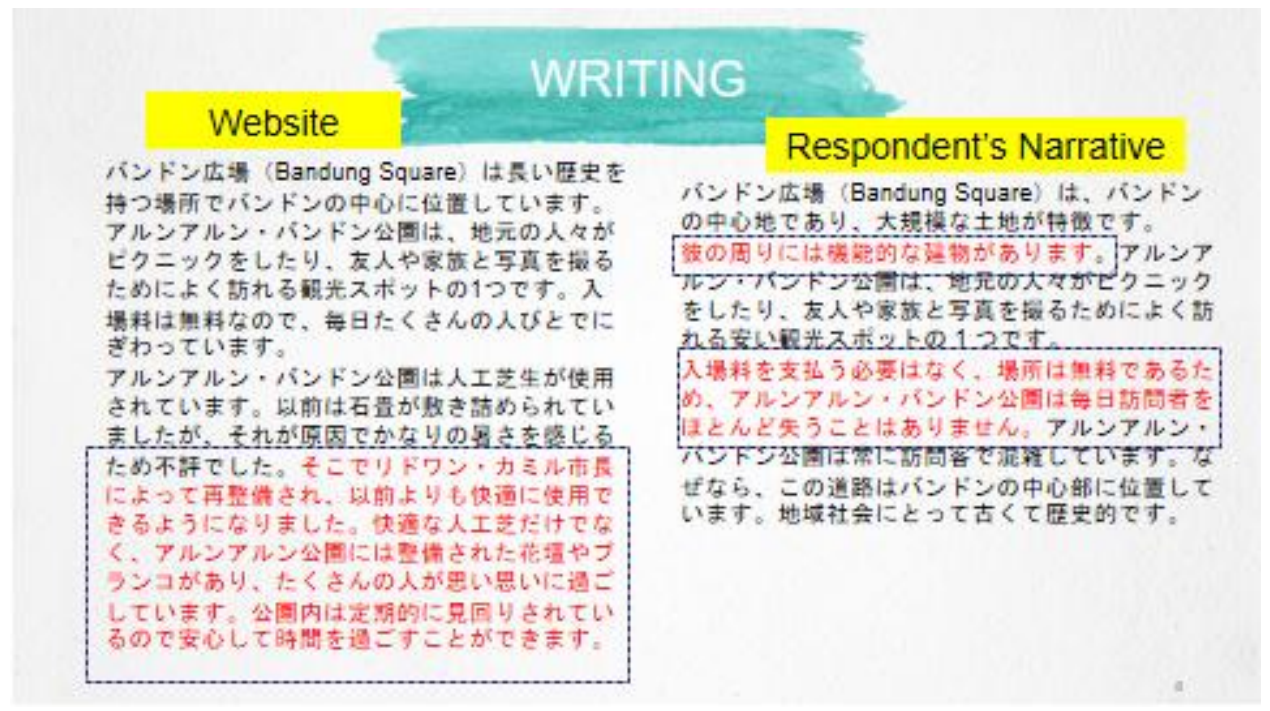

On the left is the writing found on the website while the right is written by the respondent. From the observations it is known that there is limited use of vocabulary, inconsistent use of 
structure, concept or ideas that are not explored, and errors in writing kanji. This is one example of two respondents' narratives that are incorrect in the use of Japanese. As explained earlier that from observations it is known that there is an inaccurate use of vocabulary, for example in the sentence “彼の周りには機能的な建物があります/Kare no mawari ni wa kinootekina tatemono ga arimasu”。The proper use of this vocabulary is “その周りには/Sono mawari ni $w a$ " which means 'around that'. In addition, there are also inaccurate sentences in Japanese that has the same meaning, “入場料を支払う必要はなく/Nyuujooryoo wo shiharau hitsuyou wa naku” with “場所は無料である/Basho wa muryoo dearu” which both have 'free' meanings. Furthermore, there is information on the website that was not conveyed in the narration written by respondents, namely regarding the renovation of Bandung's plaza. But besides that, there are also advantages relating to ideas in adding information.

\section{Figure 4. Writing Skills}

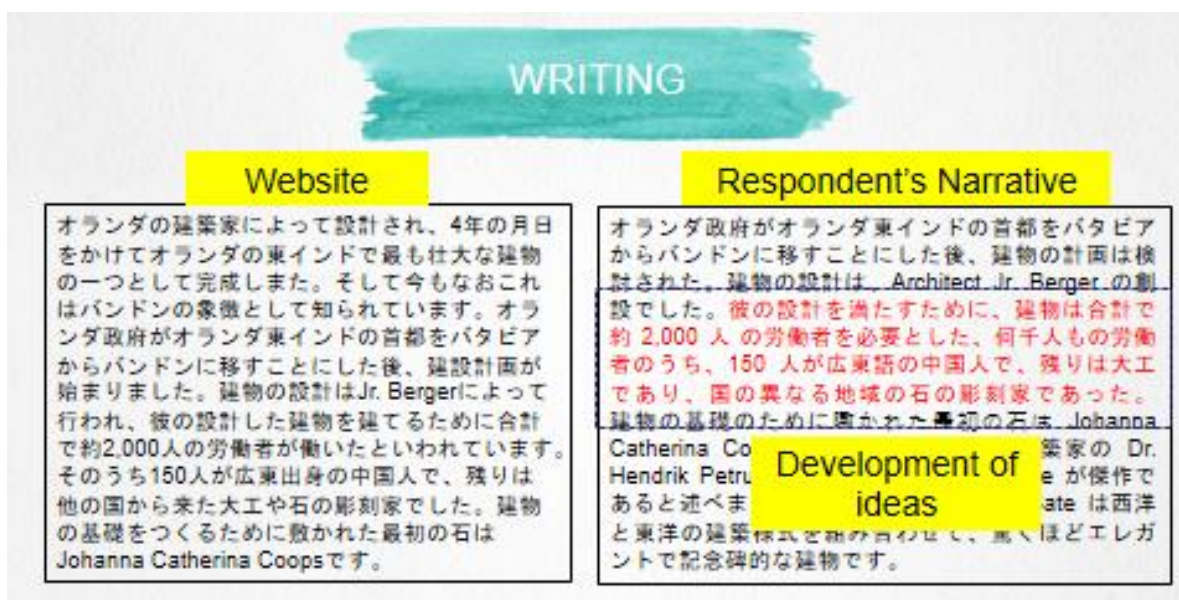

In addition to disadvantages, there are certainly advantages of a research result. From the observation, it is known that almost all respondents can develop ideas, as in this narrative. One example, as in this slide. On the website there is only information about the construction of the Gedung Sate, while the respondent's narrative is known to develop ideas, namely there are writings on the history of the Gedung Sate, how many people have built this building, and the uniqueness of the form of Gedung Sate.

As for the ability to speak can be seen from an increase of 19 points between the average pre-test value and the average post-test value. It can be assumed that respondents who were 
initially shy and refused to speak Japanese, looked more enthusiastic when speaking Japanese after being given treatment. This is because respondents can be more confident after making a presentation narrative in accordance with the theme they chose. By making a narration before the presentation can add Japanese vocabulary and explore the respondents' ideas. However, there were some respondents who presented the results by just reading the entire narration, creating inconsistent narrative structure, and the contents were written in the narration but not in the presentation.

\section{The score of pre-test and post-test in writing and speaking skills}

The study calculates the statistical data based on the results of the acquisition analysis of pre-test and post-test values to obtain the data of the improvement on learning strategy. The results of the test are:

Table 1. Data Analysis of Pre-test and Post-test Result

\begin{tabular}{|l|c|c|c|c|}
\hline \multirow{2}{*}{ Competence } & \multicolumn{2}{|c|}{ Written } & \multicolumn{2}{c|}{ Oral } \\
\hline & Total & $\sum$ & Total & $\sum$ \\
\hline Pre Test & 1050 & 70 & 975 & 65 \\
\hline Post Test & 1215 & 81 & 1260 & 84 \\
\hline
\end{tabular}

Graph 1. Total value of Pre test and Post Test in written and oral competence

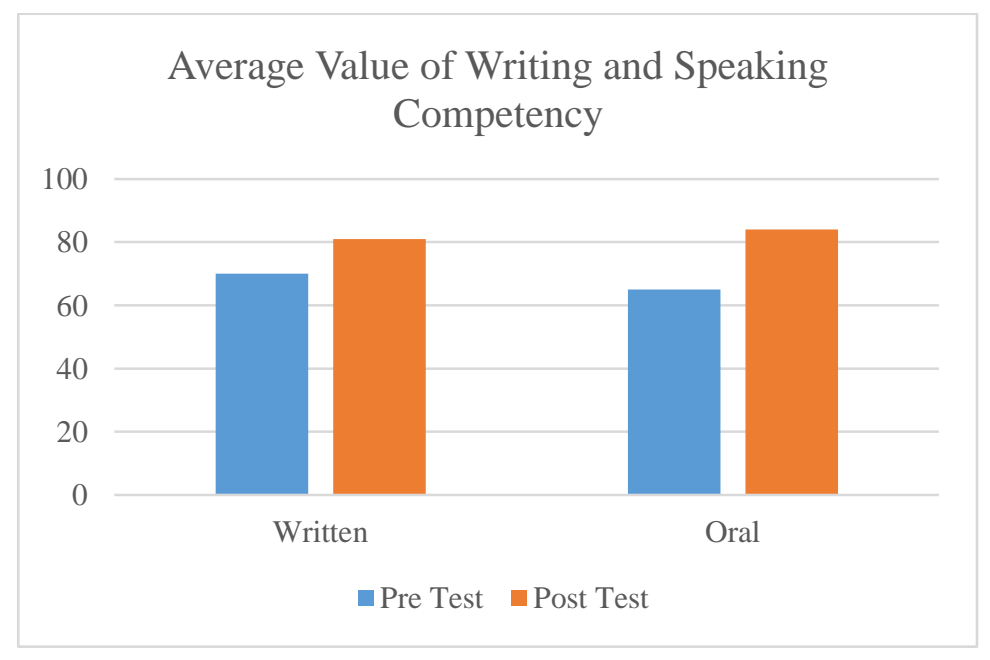

The learning strategy implemented in this study is by applying the ability to speak and write in Japanese using Website Bandung no Kankouchi. The activity is done through the project-work learning method by determining the themes contained in the websiteis favored by the students. The verbal ability of this research is emphasized through students'presentation in 
showing the explanation the themes in Website Bandung no Kankouchi. Meanwhile, the script written by the students is their activity in writing skills.

Before the learning strategy was applied, the students were embarrassed and reluctant to speak Japanese. Also, the role-playing approach still dominates the practice of speaking Japanese in the classroom. However, the combination of reading and writing to the content of tourism places in Bandung city in Japanese and the students in expressing what they see and understand.

The result from the students' writing ability is seen from the writing using sentence-pattern in the form of written language (masu keitai). The new vocabularies mastery is increased, especially the vocabularies associated with tourism, culinary, history and other general information about the city of Bandung.

The improving speaking ability is done through presentation method. Sharing thetourism destinations in Bandung city obtained from website Bandung no Kankouchi in conveying the ideas in Japanese. The speaking ability is not only measured when students do the presentations but also measured through the questioning and answering activities in Japanese.

From the results of pre-test and post-test, it is found that there is a significant impact after applying website Bandung no Kankouchi to improve students' writing and speaking skills. The assessment is done by looking at the results of students' Japanese writing and students' presentation about tourism destinations in Bandung. This learning strategy increases students' confidence in writing and speaking Japanese. Besides, students know new information about tourism destinations in Bandung.

\section{CONCLUSION}

The use of Bandung no Kankouchi website can improve the writing and speaking skills of Japanese third-year students. The results of test values show that there is a significant increase in students' understanding of information about Bandungusing Japanese. This approach contributes to the increasing students' understanding of tourism destinations in Bandung through the sharing of information during presentations and answering and questioning activities in Japanese. In addition, students can compare and discuss the tourism destinations of Bandung in Japanese.

\section{REFERENCES}

Ahmadi. M.R. (2018). The Use of Technology in English Language Learning : A Literature Review. International Journal of Research in English Education, Volume 3(2): 115. 
Dimitrov, D.M., Rumrill, P.D. (2003). Pretest-Postest Design and Measurement of Change Work, 20(2): 159-165.

Herniwati, Aneros, N., Judiasri, M.D. (2019). The Development Of Information Of Bandung's Tourism And Cultural Destinations In Japanese Language. 8th UPI-UPSI International Conference 2018. Atlantis Press. URL https://www.atlantis-press.com/proceedings/upiupsi18/55916310. ISSN: 2352-5398. P.90-97.

Medina. M. (2002). A Study of Hispanic EFL Students Learning English within a CALL Classroom: Student Introspection on Learning, Technology, and Community. Unpublished Dissertation, (India; University of Pennsylvania).

Kementerian Pariwisata. (2018). Data Kunjungan Wisatawan Mancanegara BulananTahun 2016. URL http://www.kemenpar.go.id/ asp/ringkasan.asp?c=110.

Oetomo, D., Sutedjo, B. (2007). Pengantar Teknologi Informasi. Internet: Konsep dan Aplikasi. Yogyakarta: Andi Offset.

Rusman. (2011). Pembelajaran Berbasis Teknologi Informasi dan Komunikasi. Jakarta: PT. Raja Grafindo Persada.

Sasmito. (2016). Jumlah Wisatawan Mancanegara Juli 2016 Catat Rekor Tertinggi. URL https://republika.co.id/berita/ekonomi/makro/16/09/01/octcy9382-jumlah-wisatawan mancanegara-juli-2016-catat-rekortertinggi

Soerdarsono, I.B., Wiyancoko. D. (2014). Desain Sistem dan Sarana Pemandu Wisata untuk Kota Bandung. Bandung: OJS: Jurnal Tingkat Sarjana Senirupa dan Desain ITB, 4(1) (2015).

Universitas Pendidikan Indonesia. (11 December 2019). URL https://www.bandung-nokankouchi.com 